\title{
A Study \& Survey of B.Ed. Students' Attitude towards Using Internet
}

\author{
Amit Kumar Sharma ${ }^{1}$, Rekha Pyase ${ }^{2}$, Sapna Jain ${ }^{3}$ \\ ${ }^{1}$ Assistant Professor, Department of CS\&E, Christian Eminent College, Indore, India \\ ${ }^{2,3}$ Assistant Professor, Department of Education, Christian Eminent College, Indore, India
}

\begin{abstract}
In the present investigation, an attempt has been made to study the B.Ed., Students' attitude towards using internet in pioneer and smart city (Indore) Education colleges. We are all living in the age of Information and Communication Technology (ICT). The role of computer and internet is an inevitable part of the society. Internet plays an important role in education, research and development. The student can get all information about his subjects through the relevant websites. The present study has been specifically indented to study the B.Ed., Students' attitude towards using internet in Indore City. In exact, the study aims at covering the effect of firmvariables like Gender, subject, qualification and marital status and their sub-samples. In this study also examines the strategies' to incorporate use of internet resources an associated information and communication technology tools into humanities, social, and scientific studies. Amazingly, the result showed a low percentage of internet usage in education. Also the result reveled that computer experience mainly affects how internet use in the learning process. However, there were no significant difference in the results regarding the Gender, subject, qualification and marital status.
\end{abstract}

Keywords: Attitude, Internet, ICT, Education

\section{Introduction}

As we well known that we live in scientific age and this era known as science era. One Important fact of this era is technology. In this era, main key factor of changes in social, cultural, political values is Technology. By theimprovements at technology, internet play vital role to examine these changes andinform us about changes. The main advantage of internet reaching resources fast and gathering them under the different points of views with the perspectives of equality and alternatives.Although Internet has advantages, it has shortcoming bycreating isolation, dependence and aberration issues and communities. On the other hand, iteffects the education cycle of students by providing alternatives learning styles andlearning in a creative way issues as an advantages of internet. Gaining advantage is greatoptions for everyone; internet is an aspect of changing life in order to be further step in life.

As we know that, in present time, information is everything and it forms the part of any progressive thinking. Information is being recorded, published and disseminated through several media, though the print media still dominates.

The Ministry of Education, India has recently started executing a project of Computer education in the country. It has been launched as a pilot project in collaboration with the Department of Electronics. The main objective of this project to introduced Computer Literacy and internet knowledge in Schools (class) At the primary stage, 250 schools were selected in all over the country to purview of this project and training courses were organized for the teachers in the selected Resource Centre's. Gradually all the schools would be covered in a phased manner. The main reason behind this is that day by day computers conquer an important place in our day to day life. It is known fact that there is no one field in which computer not used. Unless one has the ability to make use of computers in the respective fields, is considered to be an untrained, even though he/she is educated. Otherwise he/she is known as an educated illiterate in the modern era. Even though, having a computer is considered to be a status symbol and many are posing, as if they are using the computers effectively. They do not possess adequate knowledge about computers and their operating procedures. It is because of the fact, that many people are very much afraid of operating the computers, as the operations involve many technical terms or jargons. Therefore, on many occasions they keep themselves a little away from computer circle, even though the computers have a lot of applications and user friendly in nature. If anyone is having a favorable attitude towards computer, then may be tempted to make use of the computer and can gain knowledge about the computer. So, it is a felt need to study the attitude of people towards using internet. Therefore an attempt has been made to find out the B.Ed., students' attitude towards using internet because the B.Ed., students would be teachers, who are going to shape entire modern community.

This paper reports research carried out with B Ed students of Indore city, which investigated their attitudes towards using computers and the Internet and theirInternet usage patterns: a questionnairesurvey carried out with samples of male and female B. Ed. students of different stream.

\section{Statement of the Problem}

The problem selected for the study may be stated as "A STUDY \& SURVEY OF B.Ed. STUDENT'S ATTITUDE TOWARD'S USING INTERNET".

\section{Purposes of the Study}

This study aimed to answer the following questions:

1. What were the students' attitudes toward using Internet in their learning tasks?

\section{Volume 4 Issue 12, December 2015}




\section{International Journal of Science and Research (IJSR) \\ ISSN (Online): 2319-7064}

Index Copernicus Value (2013): 6.14 | Impact Factor (2014): 5.611

2. What were the relationships between students' gender, status, locality, gender, marital status and their attitudes toward using the Internet?

\section{Hypotheses of the Study}

The following hypotheses have been formulated. There is significant difference between

1) Science and other subject B.Ed. students,

2) Graduate and Post Graduate students,

3) Married and Unmarried students,

4) Male and Female students in respect of their attitude towards using internet.

\section{Sample}

The sample of this study consisted of 60 B. Ed. Students randomly selected enrolled in the five education college ofIndore city.

\section{Research Instrument/Tool}

The research instrument in this study was a questionnaire consistsfour sections. The first section of the questionnaire collected the students' information, like name, gender, age, locality, marital status, stream, specialization and CGPA.

The second section of the questionnaire gathered theinformation about students' basic knowledge and skills of the Internet. There were a total of six statements in this section.

The third section of the questionnaire measured the students' interest for internet topics in which he/she desires to develop own knowledge. There were a total of 10liker type statements in this section. Each question has four choices, "Great Desire" to "No Desire"

The fourth section of the questionnaire measured the students' attitudes toward the use of the Internet for learningi.e. use of internet resources \& using internet in the learning process?

Sample statements for this section were "I can download files from the internet", "I can communicate online with other students on homework / assignment", and "I can communicate online with other students on homework/assignment." There were a total of 15liker type statements each with five choices of response from "strongly disagree" to "strongly agree" in this section.

\section{Procedure}

The questionnaire was self-administered and distributed among the 60 respondents in different college on different day. Before giving the questionnaires, all questions were explained to the participants so they can easily complete the questionnaire and the relevant results. Only one questionnaire was given to each respondent. In this questionnaire, respondents were asked about which type of degree you have before this course, your age and gender, but also his attitude toward the uses of the Internet. It was difficult to distribute the questionnaire to a large number of respondents due to time constraints, lack of resources and budget. Therefore, convenient sampling method was used.

\section{Statistical Techniques}

The Statistical Techniques were used to realize the given objectives and to test the hypotheses.

1) Mean and Standard Deviation as Descriptive analysis.

2) Test of Significance (t-test)

\section{Analysis \& Interpretation}

After collecting data, and evaluating the questionnaire, 40 samples found filled correctly. The data were collected from students from Education colleges and found filled correctly, which were selected at random is as.

\begin{tabular}{|c|c|}
\hline Variables /levels & CODE \\
\hline Entire Sample & 1 \\
\hline Science Students & 2 \\
\hline Other thanScience Students & 3 \\
\hline Male Students & 4 \\
\hline Female Students & 5 \\
\hline Postgraduate Students & 6 \\
\hline GraduateStudents & 7 \\
\hline Married & 8 \\
\hline Unmarried & 9 \\
\hline
\end{tabular}

Table 1: The Details of Attitude towards Using Internet Scores of the Entire Samples And Its Sub - Samples

\begin{tabular}{|c|c|c|c|c|c|}
\hline \multirow{2}{*}{$\begin{array}{l}\text { Variables } \\
\text { /levels }\end{array}$} & \multicolumn{2}{|c|}{$\begin{array}{c}\text { Attitude towards } \\
\text { using internet }\end{array}$} & \multirow{2}{*}{$\begin{array}{l}\text { No. of } \\
\text { sample }\end{array}$} & \multirow[t]{2}{*}{ Mean } & \multirow[t]{2}{*}{ S.D. } \\
\hline & Favorable & Unfavorable & & & \\
\hline 1 & $\begin{array}{c}28 \\
(\mathbf{7 0 . 0 0 \% )}\end{array}$ & $\begin{array}{c}12 \\
(\mathbf{3 0 . 0 0 \%})\end{array}$ & -- & --- & --- \\
\hline 2 & $\begin{array}{c}20 \\
(\mathbf{8 0 . 0 0 \% )}\end{array}$ & $\begin{array}{c}5 \\
(\mathbf{2 0 . 0 0 \%}) \\
\end{array}$ & 25 & 97.000 & 15.840 \\
\hline 3 & $\begin{array}{c}8 \\
(53.33 \%)\end{array}$ & $\begin{array}{c}7 \\
(46.67 \%)\end{array}$ & 15 & 90.467 & 14.745 \\
\hline 4 & $\begin{array}{c}12 \\
\mathbf{( 7 5 . 0 0 \% )}\end{array}$ & $\begin{array}{c}4 \\
(\mathbf{2 5 . 0 0 \%})\end{array}$ & 16 & 96.938 & 15.602 \\
\hline 5 & $\begin{array}{c}16 \\
(\mathbf{6 6 . 6 7 \% )} \\
\end{array}$ & $\begin{array}{c}8 \\
(33.33 \%) \\
\end{array}$ & 24 & 92.958 & 16.031 \\
\hline 6 & $\begin{array}{c}14 \\
(\mathbf{5 8 . 3 3 \%}) \\
\end{array}$ & $\begin{array}{c}10 \\
(\mathbf{4 1 . 6 7 \% )} \\
\end{array}$ & 24 & 92.333 & 17.680 \\
\hline 7 & $\begin{array}{c}14 \\
(\mathbf{8 7 . 5 0 \%})\end{array}$ & $\begin{array}{c}2 \\
(\mathbf{1 2 . 5 0 \%})\end{array}$ & 16 & 97.870 & 11.494 \\
\hline 8 & $\begin{array}{c}11 \\
(\mathbf{7 8 . 5 7 \%})\end{array}$ & $\begin{array}{c}3 \\
(21.42 \%)\end{array}$ & 14 & 90.463 & 10.345 \\
\hline 9 & $\begin{array}{c}17 \\
(\mathbf{6 5 . 3 8 \%})\end{array}$ & $\begin{array}{c}9 \\
(34.62 \%)\end{array}$ & 26 & 96.654 & 17.602 \\
\hline
\end{tabular}

From the table it is clear that, the mean and standard deviation of the attitude towards using internet scores of the entire sample were computed., it is found that $70 \%$ of the B.Ed., students have a favorable attitude towards using internet and only $30 \%$ of them have an unfavorable attitude towards using internet. And also found that the mean range from 90.46 to 97.87 and standard deviation ranges from 10.34 to 17.68 for the entire sample 


\section{International Journal of Science and Research (IJSR) \\ ISSN (Online): 2319-7064 \\ Index Copernicus Value (2013): 6.14 | Impact Factor (2014): 5.611}

Table 2: The Significance of the Difference between the Means of the Attitude towards Using Internet Scores of Different Samples.

\begin{tabular}{|c|c|c|c|c|c|c|c|}
\hline Samples & $\begin{array}{c}\text { Sub- } \\
\text { Samples }\end{array}$ & Number & Mean & S.D & DF & $\begin{array}{l}\text { T- } \\
\text { test }\end{array}$ & $\begin{array}{c}\text { Significance } \\
\text { at the } 0.05 \\
\text { level }\end{array}$ \\
\hline \multirow{2}{*}{ Stream } & 2 & 25 & 97.00 & 15.84 & \multirow{2}{*}{38} & \multirow{2}{*}{1.295} & \multirow{2}{*}{$\begin{array}{c}\text { No } \\
\text { significance }\end{array}$} \\
\hline & 3 & 15 & 90.46 & 14.75 & & & \\
\hline \multirow{2}{*}{ Gender } & 4 & 16 & 96.94 & 15.06 & \multirow{2}{*}{38} & \multirow{2}{*}{0.787} & \multirow{2}{*}{$\begin{array}{c}\text { No } \\
\text { significance }\end{array}$} \\
\hline & 5 & 24 & 92.96 & 16.03 & & & \\
\hline \multirow{2}{*}{$\begin{array}{c}\text { Pre- } \\
\text { Degree }\end{array}$} & 6 & 24 & 92.33 & 17.69 & \multirow{2}{*}{38} & \multirow{2}{*}{1.105} & \multirow{2}{*}{$\begin{array}{c}\text { No } \\
\text { significance }\end{array}$} \\
\hline & 7 & 16 & 97.87 & 11.49 & & & \\
\hline \multirow{2}{*}{$\begin{array}{l}\text { Marital } \\
\text { Status }\end{array}$} & 8 & 14 & 90.46 & 10.35 & \multirow{2}{*}{38} & \multirow{2}{*}{1.169} & \multirow{2}{*}{$\begin{array}{c}\text { No } \\
\text { significance }\end{array}$} \\
\hline & 9 & 26 & 96.65 & 17.6 & & & \\
\hline
\end{tabular}

Table 2 shows significance of the hypothesis, from the table following observation made. First all, the significance difference were taken at 0.005 level. The hypothesis were took initially become reverse. For all observation Samples (as stream, gender, Pre-degree, marital status) there is no significant difference foundbetween the means of the attitude towards using internet scores of different samples.

From the table 2, it is clear that the degree of freedom for all samples is 38. For sample stream i.e. science student and other than science student the mean achievement score was97.00 \&90.46 and S.D. value was $15.84 \& 14.75$ respectively. The t-value of difference between these two mean scores was 1.295 which was greater than the tabulated value 1.701 Thus; the obtained t-value was significant at 0.05 level. Therefore new null hypothesis is accepted and it is concluded that there is no significant difference between the science student and other than science student in respect of their attitude towards using internet.

For sample Gender i.e. male and female student the mean achievement score was $15.06 \& 16.03$ and S.D. value was 96.94\&92.96respectively. The t-value of difference between these two mean scores was 0.787 which was greater than the tabulated value 1.701 Thus; the obtained t-value was significant at 0.05 level. Therefore new null hypothesis is accepted and it is concluded that there is no significant difference between the male and female students in respect of their attitude towards using internet.

For sample stream i.e. Pre-degree of student the mean achievement score was $17.69 \& 11.49$ and S.D. value was $90.46 \& 96.65$ respectively. The t-value of difference between these two mean scores was 1.169 which was greater than the tabulated value 1.701 Thus; the obtained t-value was significant at 0.05 level. Therefore new null hypothesis is accepted and it is concluded that there is no significant difference between on the basis of Pre-degree of student students in respect of their attitude towards using internet.

For sample marital status of studentsthe mean achievement score was $10.35 \& 17.60$ and S.D. value was $15.84 \& 14.75$ respectively. The t-value of difference between these two mean scores was 1.295 which was greater than the tabulated value 1.701 Thus; the obtained t-value was significant at 0.05 level. Therefore new null hypothesis is accepted and it is concluded that there is no significant difference found on the basis of marital status of students in respect of their attitude towards using internet.

\section{Discussions}

The findings got out by the study are prescribed. In the present study maximum students have a favorable attitude towards using internet. This gets support from a few earlier studies.

Gender and pre-qualification of the students causes no significant difference in respect of their attitude towards using internet in the present study. This also gets support from a few earlier studies.From the result obtained the important findings of the study In respect of the entire sample of the B.Ed., students, as much as $70 \%$ of them have a favorable attitude towards using internet and $30 \%$ of them have an unfavorable attitude towards using internet.There is no significant difference between the male and female, among the Science, other than Science, graduate and postgraduate qualified, married and unmarried B.Ed. students in respect of their attitude towards using internet.

\section{Conclusion}

Results of the study reveal that the students were familiar with Internet use and also used it regularly. Most had access to the Internet at home/cyber cafe daily at least 1-2 hour daily. They used this technology mostly for communication and educational purpose. A majority of users had no formal training. They preferred to contact their friends or relatives for solving problems in Internet use. Their attitude towards the tools and services of the Internet was positive. Users agreed that the Internet was very helpful in meeting their information and communication requirementspromptly.

\section{References}

[1] Bijoy K. Thomas : A Study of Attitude of Student and Educators towards ICT, Journal of Global Economy, Volume 5 No2, APRIL-JUNE, 2009

[2] Dr.M.Suganthi: Attitude of B.ed. Students Towards Information and Communication Technology, Indian Journal Of Applied Research, Volume : 3 | Issue : 9 | Sept 2013 | ISSN - 2249-555X

[3] B.V. Gopal and K. Anandan: Attitude towards eLearning in Classroom Instruction among the B.Ed. Students at Colleges of Education, available at www.languageinindia.com

[4] Indian Streams Research Journal , International MultidisciplinaryResearch Journal, Vol 4 Issue 7 Aug 2014, ISSN No : 2230-7850

[5] Dr. Aytekin ISMAN: Attitudes of Students Towards Internet, Turkish Online Journal of Distance EducationTOJDE October 2004 ISSN 1302-6488 Volume: 5 Number: 4

[6] Adel Ben Youssef ,MounirDahmani: The Impact of ICT on Student Performance in Higher Education: Direct Effects, Indirect Effects and Organisational Change, rusc vol. 5 n. ${ }^{\circ} 1$ (2008) | ISSN 1698-580x. 


\section{International Journal of Science and Research (IJSR) \\ ISSN (Online): 2319-7064}

Index Copernicus Value (2013): 6.14 | Impact Factor (2014): 5.611

[7] Gary S. Nickell : Computer Attitude Scale, Minnesota State University Moorhead John N. Pinto, Morningside College

[8] Nickell, G. S., \& Pinto, J. N. (1986). The computer attitude scale. Computers in Human Behavior, 2, 301306.

[9] Muhammad Safdar, IrshadHussain, et. al., Challenges Of Information Era: Teachers' Attitude Towards The Use Of Internet Technology,

[10] Khalid Mahmood: Gender, subject and degree differences in university students' access, use and attitudes toward information and communication technology (ICT), International Journal of Education and Development using Information and Communication Technology (IJEDICT), 2009, Vol. 5, Issue 3, pp. 206-216

[11] Nai Li, Gill Kirkup: Gender and cultural differences in Internet use: A study of China and the UK, available online at www.sciencedirect.com

[12] Internet use and attitudes bulletin 2012

[13] Patrick M. Scanlon, David R. Neumann: Internet Plagiarism Among College Students, Journal of College Student Development, MAY/JUNE 2002, VOL 43 NO 3

[14] Hong, K.-S., Ridzuan, A. A., \&Kuek, M.-K. (2003). Students' attitudes toward the use of the Internet for learning: A study at a university in Malaysia. Educational Technology \& Society, 6(2), 45-49, Available at http://ifets.ieee.org/periodical/6-2/5.html

[15] Sam, H. K., Othman, A. E. A., \&Nordin, Z. S. (2005). Computer Self-Efficacy, Computer Anxiety, and Attitudes toward the Internet: A Study among Undergraduates in Unimas. Educational Technology \& Society, 8 (4), 205-219.

[16] Busch, T. (1995). Gender differences in self-efficacy and attitudes toward computers. Journal of Educational Computing Research, 12, 147-158.

[17] Kinzie, M. B., Delcourt, M. A. B., \& Powers, S. M. (1994). Computer technologies: Attitudes and selfefficacy across undergraduate disciplines. Research in Higher Education, 35, 745-768.

[18] Consultation on 'National Policy on ICTs in School Education', April 29th-30th, 2008 New Delhi

[19] Swapna Kumar and MaijaTammelin; Integrating ICT Into Language Learning And Teaching, ODLAC | guide for Institutions.

[20] Niraj Kumar Roy: ICT-Enabled Rural Education in India, International Journal of Information and Education Technology, Vol. 2, No. 5, October 2012 